\title{
Realising Universal Suffrage in Hong Kong After the Standing Committee's Decision
}

\author{
Simon N.M. Young* \\ October 2014
}

Of all the preconditions to realising universal suffrage of Hong Kong's Chief Executive in 2017, the most challenging is getting two-thirds of the 70 legislators to agree on a reform proposal. On 31 August 2014, the Standing Committee of the National People's Congress made this challenge even more difficult by imposing restrictive and controlling conditions on the nomination process. The decision sparked unprecedented protests and acts of civil disobedience on the streets of Hong Kong in September and October 2014. Legislators have until the middle of 2015 to assess whether they can agree with the central and local governments on a single reform proposal. This paper assesses the arguments for and against reform, within the constraints of the Standing Committee's decision. It argues in favour of reform so long as there are sufficient reassurances and measures to regain the trust of the Hong Kong people. The complete reform proposal will need to have sufficient safeguards and counter-balances to ensure that the central government does not control both the nomination and election results. All stakeholders need to take positive steps to make for more favourable reform conditions.

\section{Introduction}

Realising universal suffrage in Hong Kong first requires the Standing Committee of the National People's Congress (NPCSC) to decide there is a need to amend the method for selecting the Chief Executive (CE) in the year 2017. Thereafter, the amendment formulae requires the proposed universal suffrage reform to have the endorsement of two-thirds majority of all 70 members of the Legislative Council ( $\mathrm{LegCo}$ ), the consent of the $\mathrm{CE}$, and the

\footnotetext{
*Professor and Associate Dean (Research), Faculty of Law, The University of Hong Kong. This paper was presented at the Conference on "Universal Suffrage for the Election of the Chief Executive: 2017 and Beyond", 20 September 2014, City University of Hong Kong, Hong Kong. (C) 2014.

${ }^{1}$ The Interpretation by the NPCSC of Article 7 of Annex I and Article III of Annex II to the Basic Law of the Hong Kong Special Administrative Region of the People's Republic of China, adopted 6 April 2004, $8^{\text {th }}$ Sess. of the Standing Committee of the $10^{\text {th }}$ NPC, Art. 3, accessible at www.2017.gov.hk ("2004 Interpretation").
} 
approval of the NPCSC. ${ }^{2}$ On 31 August 2014, the NPCSC decided there was a need to amend the current method to allow for the implementation of universal suffrage in 2017, but imposed restrictive conditions on the nomination process. ${ }^{3}$ Following the decision, both the CE and NPCSC expressed hope that a reform proposal could be agreed upon in order to realise universal suffrage. ${ }^{4}$ Less clear was whether two-thirds of legislators were prepared to negotiate and accept a reform proposal. All 27 pan-democratic legislators (who hold a veto over the reform vote, by a margin of five votes) have vowed to reject any reform proposal, irrespective of public opinion, and to boycott the second round of government consultation. ${ }^{5}$

This paper considers the arguments for and against accepting a universal suffrage model from the standpoint of legislators. It argues that if legislators are rational actors who act solely in the public interest then on balance the arguments in favour of accepting a reform proposal outweigh those against. However logical arguments alone will not be enough to win over pandemocratic legislators. As a matter of political reality, the four major stakeholders (central government, Hong Kong Special Administrative Region (HKSAR) government, HKSAR legislators and HKSAR electorate) need to take steps to bring about favourable conditions to realising universal suffrage. Some of those steps and conditions will be discussed in this paper.

\section{Should Legislators Vote for Reform?}

The arguments for and against reform appeal to general considerations of the public interest. No dogmatic positions are adopted one way or another. For example, it would be unproductive to argue that because the NPCSC decision will necessarily lead to a proposal that violates Article 25 of the International Covenant on Civil and Political Rights (ICCPR) we must in principle reject any reform. Breach of Article 25 may involve state responsibility at the

\footnotetext{
${ }^{2}$ The Basic Law of the Hong Kong Special Administrative Region of the People's Republic of China, promulgated 4 April 1990, Annex I, Art. 7 ("Basic Law").

${ }^{3}$ Decision of the NPCSC on Issues Relating to the Selection of the Chief Executive of the HKSAR by Universal Suffrage and on the Method for Forming the Legislative Council of the HKSAR in the Year 2016, adopted 31 August 2014, $10^{\text {th }}$ Sess. of the Standing Committee of the $12^{\text {th }}$ NPC, accessible at www.2017.gov.hk (" 2014 Decision"). Those restrictions were that (1) "the number of members, composition and formation method of the nominating committee shall be made in accordance with the number of members, composition an formation method of the Election Committee for the Fourth Chief Executive"; (2) the "nominating committee shall nominate two to three candidates... in accordance with democratic procedures; (3) each candidate "must have the endorsement of more than half of all the members of the nominating committee" (see Art. II).

${ }^{4}$ Li Fei, Explanations on the Draft Decision of the NPCSC on Issues Relating to the Selection of the Chief Executive of the HKSAR by Universal Suffrage and on the Method for Forming the Legislative Council of the HKSAR in the Year 2016, 27 August 2014, $10^{\text {th }}$ Sess. of the Standing Committee of the $12^{\text {th }}$ NPC, accessible at www.2017.gov.hk (“2014 Explanations"), p. 3; C.Y. Leung, "CE's 'Letter to Hong Kong”, Press Release, 14 Sept 2014, accessible at http://www.info.gov.hk/gia/general/201409/14/P201409120972.htm.

${ }_{5}^{5}$ Joyce Ng \& Kristine Kwok, "Hong Kong's pan-democrats face a steep climb to universal suffrage", South China Morning Post, 15 Sept 2014.
} 
international level but for now our concern is with the domestic sphere. ${ }^{6}$ The current debate centres not on pure legal questions but involves a political process of constitutional reform. A wider array of considerations needs to be taken into account in considering whether there should be reform in the public interest.

\section{Arguments in Favour of Reform}

There are three main arguments in favour of reform. The first is that universal suffrage will produce a $\mathrm{CE}$ that is more accountable to Hong Kong people than all previous CEs. ${ }^{7}$ The $\mathrm{CE}$ will need to pay closer attention to the needs and demands of the people. The $\mathrm{CE}$ as a candidate will have to develop peoplebased policies and demonstrate an ability to deliver on these policies if he/she is to win the support of the electorate. A $50 \%$ minimum vote that permits blank votes to be cast can ensure demonstrated majority support by the people and counterbalance the influence of the central government in the nomination process. The prospect of re-election and a second term of office will help sustain public accountability. This consideration would not apply directly to a serving second term CE (e.g. if the incumbent CE was to be reelected in 2017) because of the two-term cap. ${ }^{8}$ However, assuming CEs will be allowed to maintain political party affiliation, the second term $\mathrm{CE}$ will not want to jeopardize the chances of someone in his/her political camp from being elected after he/she steps down. ${ }^{9}$

I believe this first argument carries a significant amount of weight. All previous CEs were too closely aligned with the central government and the small circle electorate of the Election Committee, which was/is disproportionately representative of business, industrial and professional interests. ${ }^{10}$ There was no real accountability to the people. For this reason alone, universal suffrage will bring about a fundamental shift in our political environment. This is a shift that furthers autonomy and self-government.

The second argument is that with universal suffrage of the CE we will be in a better position to have more democratic political reform in the future. The

\footnotetext{
${ }^{6}$ See Responsibility of States for Internationally Wrongful Acts 2001, UNGA resolution 56/83, 12 Dec 2001; James Crawford, Rights in One Country: Hong Kong and China (Hong Kong: Faculty of Law, University of Hong Kong, 2005) 29.

${ }^{7}$ Under the Basic Law, the CE is "accountable to the Central People's Government and the Hong Kong Special Administrative Region" (Art. 43).

${ }^{8}$ Basic Law, Art. 46.

${ }^{9}$ Section 31(1) of the Chief Executive Election Ordinance (Cap. 569) requires the elected CE to declare publicly that he/she "is not a member of any political party" within seven working days of being officially declared the winning candidate. See also Simon NM Young \& Richard Cullen, Electing Hong Kong's Chief Executive (Hong Kong: HKU Press, 2010) 101-102 (“Electing Hong Kong's Chief Executive").

${ }^{10}$ Joseph Y.S. Cheng (ed), The Second Chief Executive of Hong Kong SAR: Evaluating the Tsang Years 20052012 (Hong Kong: City University of Hong Kong Press, 2013) ix-xxii \& 23-24; Law Siu-kai (ed), The First Tung Chee-hwa Administration: The First Five Years of the Hong Kong Special Administrative Region (Hong Kong: Chinese University Press, 2002) 243-245.
} 
two major reform exercises that the $2017 \mathrm{CE}$ would have to tackle are 2020 LegCo universal suffrage and the second CE universal suffrage election in 2022. ${ }^{11}$ There is a real risk (a la the position taken on the 2016 LegCo vote) that no change will be made to the $2022 \mathrm{CE}$ vote because of preoccupation with the 2020 LegCo vote. ${ }^{12}$ But LegCo universal suffrage alone could see either abolition or transformation of the functional constituency seats and this would also constitute another fundamental shift in our system. Having a greater proportion of more directly elected legislators will also change the composition of the Nominating Committee, although the change will not be great. ${ }^{13}$

I also believe the second argument is a strong one. There is no reason to believe at present that by standing still (i.e. if legislators veto 2017 universal suffrage) we will be able to achieve a more liberal nomination process for either the 2017 or $2022 \mathrm{CE}$ elections. More likely than not the incumbent CE will be re-elected in 2017 by the 1200 member Election Committee and effectively there will be no greater prospects of change. We already know for sure that vetoing 2017 universal suffrage means that LegCo universal suffrage will need to wait until 2024 and more likely 2028 at the earliest. ${ }^{14}$ Acceptance of 2017 universal suffrage, albeit compromised, is surely the better way to realise more comprehensive universal suffrage earlier. Also, a more publicly accountable $\mathrm{CE}$ will be in a better position to bring further and better changes to the universal suffrage system. As we know from the NPCSC's 2004 decision and from the past decade of experience, the CE's report to the NPCSC plays a crucial role in the process of political reform. ${ }^{15}$

Thirdly it can be argued that the $2017 \mathrm{CE}$ elected by universal suffrage will be more likely and able to overcome the governance issues that have plagued Hong Kong since 1997. Policymaking and law reform have been severely crippled by poor relations between the executive and legislative branches and a deeply divided legislature. A publicly accountable CE will work harder to come up with policies and reforms that have the support of legislators and thereby defuse the tensions that have developed since the first CE's administration.

\footnotetext{
${ }^{11}$ Decision of the NPCSC on Issues Relating to the Methods for Selecting the Chief Executive of the HKSAR and for Forming the Legislative Council of the HKSAR in the Year 2012 and on Issues Relating to Universal Suffrage, adopted 29 Dec 2007, $35^{\text {th }}$ Sess. of the Standing Committee of the $10^{\text {th }}$ NPC, Art. 3, accessible at www.2017.gov.hk ("2007 Decision").

${ }^{12}$ See 2014 Decision, Para. 5 \& Art. V; Report by the Chief Executive of the HKSAR to the NPCSC on whether there is a need to amend the methods for selecting the Chief Executive of the HKSAR in 2017 and for forming the Legislative Council of the HKSAR in 2016, [11(x)] ("CE Report 2014").

${ }^{13}$ All legislators are ex-officio members of the fourth sector of the nominating committee to be. If all legislators were directly elected then this only affects 12 percent of the fourth sector composition and only three percent of the overall committee membership.

${ }^{14}$ Given the 2013 to 2015 timetable to pass and implement CE universal suffrage reforms, two years will not be enough for the $2022 \mathrm{CE}$ to introduce universal suffrage for the $2024 \mathrm{LegCo}$ election.

${ }^{15}$ Regrettably the CE Report 2014 was not written in terms intended to influence the NPCSC to adopt a more liberal nomination regime.
} 
This third argument will probably carry less weight in the short term. I agree with the views of Danny Gittings who argues that universal suffrage on whatever model is not a panacea to the governance problems we have been experiencing. ${ }^{16}$ Other measures will be needed because the problems stem from more entrenched factors such as the principle of separation of powers and other constitutional constraints. I believe we will need to wait until LegCo universal suffrage is realised before we see greater harmony between the legislative and executive branches. It is the 50:50 geographical and functional constituencies membership constraint that had significantly contributed to the dividedness of the legislature and precluded a strong executive government. ${ }^{17}$ While a directly elected $2017 \mathrm{CE}$ might be more inclined to initiate a process of power sharing with legislators, it will probably require one or two more $\mathrm{CE}$ terms for this practice to mature.

\section{Arguments Against Reform}

There are also three main arguments against reform. Perhaps the strongest argument is the one based on trust or more appropriately distrust. Many have expressed emotions of feeling cheated after the NPCSC's August decision. ${ }^{18}$ It was highly unexpected that the NPCSC would take such a conservative and restrictive stance on the nomination process. ${ }^{19}$ Clearly public expectations were poorly managed. It follows that if the central government could renege on $\mathrm{CE}$ universal suffrage, it could easily renege on any concessions made to lure legislators to accept the reform proposal and also renege on LegCo universal suffrage. In particular, the common understanding that functional constituencies in their current form are inconsistent with universal suffrage could well be a fiction in the mind of the central government. ${ }^{20}$ It is clear that international law standards mean nothing to the central government. ${ }^{21}$ Unless these doubts can be

\footnotetext{
${ }^{16}$ See Danny Gittings, "Separation of Powers and Universal Suffrage", paper for Conference on "Universal Suffrage for the Election of the Chief Executive: 2017 and Beyond", 20 Sept 2014, School of Law, City University of Hong Kong.

172007 Decision, Art. 1.

${ }^{18}$ Peter So \& Tony Cheung, "Pan-democrats abandon 'pointless' negotiations over Hong Kong electoral reform”, South China Morning Post, 11 Sept 2014; Peter So, Tony Cheung \& Gary Cheung, "Beijing's 'ultraconservative' reform plan disappoints former minister Frederick Ma”, South China Morning Post, 8 Sept 2014.

${ }^{19}$ Alex Lo, “Are some Hong Kong pan-democrats stepping away from the brink?", South China Morning Post, 3 Sept 2014.

${ }^{20}$ In 2010, the then Secretary for Constitutional and Mainland Affairs, Mr. Stephen Lam, acknowledged that the electoral method for the functional constituencies at that time did not comply with the principles of universality and equality, see "LCQ5: Functional constituencies", Press Release, 26 May 2010, accessible at http://www.info.gov.hk/gia/general/201005/26/P201005260149.htm.

${ }^{21}$ See Regina Ip, "The logic of Beijing's vision for 2017 chief executive election", South China Morning Post, 31 Aug 2014; "Government responds to media enquiries on 'civil referendum results", Press Release, 29 June 2014, accessible at http://www.info.gov.hk/gia/general/201406/29/P201406290926.htm. But contrast with the Centre for Comparative and Public Law's Guiding Principles on the Compatibility of Election Mechanisms and Methods with International Standards: Outcomes of the Academic Roundtable on "Universal Suffrage and Nomination Procedure: Imperatives from Article 25 ICCPR", 21 March 2014, accessible at
} 
removed, then there is no point in thinking that there can be better political reform with a directly elected $2017 \mathrm{CE}$.

In the post-NPCSC decision climate, the issue of distrust is a real concern and for some will tip the balance against reform. It remains unclear whether NPCSC members had the restrictions in mind all along or whether the restrictions were the product of recent events. The NPCSC's Deputy Secretary General (Li Fei)'s explanations on the draft August decision referred to recent events as being matters of concern: "A small number of people have even raised views that are contrary to the Hong Kong Basic Law and openly advocated illegal activities." "2 It was said that these developments "will inevitably undermine the rule of law...the interests of Hong Kong residents and foreign investors and the long-term prosperity and stability of Hong Kong, and hence merit close attention" (emphasis added). ${ }^{23}$ These remarks suggest that the strict conditions were triggered by the many calls for civic nomination and the Occupy Central campaign. ${ }^{24}$

However, in Li Fei's explanation of the individual parts of the decision, he appealed to the terms of the Basic Law and the NPCSC's previous decisions/interpretation. ${ }^{25}$ This suggests the restrictions are implicit in these legal instruments and thus a permanent feature of the CE universal suffrage system. If this is the true position, then the central government can be faulted for not making these features known earlier. Why did it allow the Hong Kong government to conduct such an open-ended consultation that invited proposals inconsistent with the restrictions and raised false hopes of a flexible range of possible implementation methods? This poor management of public expectations greatly damaged the trust between Hong Kong people and both the central government and HKSAR government.

Unless steps are taken to repair this lack of trust, this is a weighty reason not to accept any reform proposal. I remain of the view however that steps can still be taken to address the issue of trust, but all sides must be willing to listen and negotiate with the other. It will require positive and authoritative statements from the central and Hong Kong governments sufficient to reassure Hong Kong legislators and members of the public. They must be statements that engender confidence in the development of LegCo universal suffrage and the further development of CE universal suffrage. They must be clear and

\footnotetext{
http://www.law.hku.hk/ccpl/events/CCPL\%20Article\%2025\%20Roundtable\%20Press\%20Release\%20on\%20G uiding\%20Principles\%2021\%20March\%202014.pdf.

${ }^{22} 2014$ Explanations, [5].

${ }^{23} \mathrm{Ibid}$.

${ }^{24}$ Chris Buckley \& Michael Forsythe, "China Restricts Voting Reforms for Hong Kong", International New York Times, 31 Aug 2014; Joseph Wang, "Why did Beijing take such a hard line against direct elections in Hong Kong?", Quora, 5 Sept 2014, accessible at http://www.quora.com/Why-did-Beijing-take-such-a-hardline-against-direct-elections-in-Hong-Kong; Johnny Lau, "The root of Beijing's iron fist", Harbour Times, 18 Sept 2014, p 5.

${ }^{25} 2014$ Explanations, Section 2. See also Jeffie Lam, "Half of Hongkongers sway lawmakers should veto Beijing's electoral reform plan”, South China Morning Post, 15 Sept 2014.
} 
specific, sufficient to ground a legitimate expectation in public law. ${ }^{26}$ The possible content of these official statements of reassurance together with proposed actions to back up these statements are discussed below.

The second argument against reform is the fear that the $2017 \mathrm{CE}$ would be even worse than previous CEs because, not only would the central government have choice over the candidate through the nominating committee, the selection of the chosen candidate by the people would lend the process and candidate an air of legitimacy. ${ }^{27}$ With such apparent legitimacy, people will be less inclined to challenge the system.

This argument presupposes that the central government will be able to control and sway voter choice amongst the Hong Kong electorate. This has yet to be seen. If voters are given the option of casting meaningful blank votes then it will be more difficult to predetermine the final election outcome. The election context must also be taken into account. Hong Kong has a robust and independent legal system to deal with corruption issues and fairness in the election process. ${ }^{28}$ We have seen from the two previous CE elections that the media freely investigates, reports and imparts information that can inform and affect election results. ${ }^{29}$ Televised public debates amongst the candidates are now established practices expected by the public; these debates can also affect public opinion of the candidates. ${ }^{30}$ While it is still open for agents and sympathizers of the central government to try to influence public opinion, this occurs in a climate of open competition with other groups also trying to influence election results. Without an ability to control public opinion, the central government will need to gauge public opinion closely when deciding on their support for potential candidates. In the Hong Kong environment, it is the free flow of information and public opinion that affects central government decision-making and not the other way around. If the general electorate has the final say on either the winning candidate or, with blank votes, rejection of all candidates then it cannot be said that the directly elected $2017 \mathrm{CE}$ will be worse than previous CEs. As mentioned above, the office of CE will have a form of public accountability, which it has never had before. A public commitment to review the $\mathrm{CE}$ election system with a view to reform will send the message that the system is not perfect and still evolving.

The third argument against reform is that by "pocketing" $2017 \mathrm{CE}$ universal suffrage, it will be next to impossible to further develop the CE

\footnotetext{
${ }^{26}$ See $\mathrm{Ng}$ Siu Tung $v$ The Director of Immigration (2002) 5 HKCFAR 1.

27 Alan Leong, "Letter to Hong Kong", RTHK, 8 June 2014, accessible at http://podcast.rthk.hk/podcast/item_epi.php?pid=162\&lang=en-US\&id $=42528$.

${ }^{28}$ See Elections (Corrupt and Illegal Conduct) Ordinance (Cap. 554); Law Kin Man v Leung Wai Kuen Edward, unreported, FAMV11/2013, 11 July 2013, CFAAC; Mok Charles Peter v Tam Wai Ho (2012) 15 HKCFAR 489; Secretary for Justice v Ho Chun Yan, Albert (2013) 16 HKCFAR 735; HKSAR v Kan, Brian Ping Chee, unreported, FAMC64/2012, 9 Aug 2013, CFAAC.

${ }^{29}$ See Young \& Cullen, Electing Hong Kong's Chief Executive, pp. 86-90; Teddy Ng \& Gary Cheung, "Election debate enthralls and dismays mainlanders", South China Morning Post, 12 March 2012.

${ }^{30}$ Regina Ip, “The power of public opinion”, South China Morning Post, 1 April 2012.
} 
election system in the future. ${ }^{31}$ As mentioned above, I fear this may be true for the 2022 CE election simply because the enormous task of realizing 2020 LegCo universal suffrage is likely to eclipse any major reform for 2022. But assuming both LegCo and the CE are elected by universal suffrage by the time the $2022 \mathrm{CE}$ is elected then it is only reasonable to assume that there will be support from the $\mathrm{CE}$ and legislators for a more democratic $\mathrm{CE}$ election system in 2027, especially if very little reform takes place in 2022. Any further predictions on 2027 can only involve speculation. Though further reform of the CE system will be slow and gradual, I believe that it will still be faster than standing still in 2017 and hoping for a miracle that the central government will decide a more liberal nomination process for 2022 or 2027.

After weighing the arguments for and against reform, the arguments in favour of reform tend to outweigh those against but only if the feelings of distrust with the central and regional governments can be adequately addressed. What steps and measures can be taken by all stakeholders to generate more favourable conditions for reform will be discussed in the next section.

\section{Generating More Favourable Reform Conditions}

The current political impasse should not be seen simply as an issue of the central and regional governments making reform concessions to secure the support of five of the 27 pan-democrat legislators. ${ }^{32}$ All four major stakeholder groups (central and regional governments, legislators and Hong Kong electorate) can take positive steps to bring about more favourable conditions for reform. Given that the issue of trust is the major obstacle to reform, negotiations between the parties should go beyond the $2017 \mathrm{CE}$ election system and extend to other matters of significant concern including the $2020 \mathrm{LegCo}$ election and the implementation of Article 23 of the Basic Law (national security laws). ${ }^{33}$

\footnotetext{
${ }^{31}$ See Margaret Ng, "Hong Kong's Democracy Dilemma", International New York Times, 2 Sept 2014.

${ }^{32}$ The HKSAR government is short five votes to having two-thirds majority support from legislators for any reform proposal. See Chris Yeung, "The battle to govern", Harbour Times, 3 Sept 2014.

${ }^{33}$ Article 23 of the Basic Law requires the HKSAR to enact "on its own" laws to prohibit any act of treason, secession, sedition, subversion against the central government or theft of state secrets, to prohibit foreign political organizations or bodies from conducting political activities in the HKSAR and to prohibit political organizations or bodies of the HKSAR from establishing ties with foreign political organizations or bodies. An attempt to enact such laws failed in 2003. See Fu Hualing, Carole J Petersen \& Simon NM Young, National Security and Fundamental Freedoms: Hong Kong's Article 23 Under Scrutiny (Hong Kong: HKU Press, 2005). The references to "national security" in the 2014 Decision and 2014 Explanations raise concerns that the return of the Article 23 issue is not too distant. See Johnny Lau, "The root of Beijing's iron fist", Harbour Times, 18 Sept 2014, p 5.
} 


\section{Central Government}

On the issue of trust, the ball is plainly in the central government's court. As mentioned above, making official statements of reassurance backed with action may help to address the mistrust that has resulted from the NPCSC's highly unexpected and conservative August decision. It should try to understand the issues of greatest concern to the Hong Kong people and legislators. Probably the three issues of greatest concern at present are whether the restrictions on nomination specified in the August decision can be changed in the future, ${ }^{34}$ whether LegCo's functional constituencies in their current form are consistent with the meaning of universal suffrage in Article 68 of the Basic Law, and whether the $2017 \mathrm{CE}$, elected by universal suffrage, will have to implement Article 23. Statements along the following lines could be adopted:

1. CE Nomination Statement: After the election of the CE by universal suffrage, the NPCSC may decide to adopt provisions different from those in Article II of the NPCSC's Decision of 31 August 2014 in respect of future $\mathrm{CE}$ elections.

2. Functional Constituencies Statement: The current use of functional constituencies to elect half of the members of the LegCo is not in conformity with the ultimate aim of electing members of LegCo by universal suffrage under Article 68 of the Basic Law.

3. Article 23 Statement: The HKSAR Government can decide on its own when it will enact laws to implement fully Article 23 of the Basic Law

The statements should come from the Chairman of the NPCSC, in a supplementary Decision of the NPCSC or in the amendment Decision itself.

To demonstrate its sincerity, the central government should also leave many if not all of the remaining political reform issues to the regional government to settle. It should make clear that the Hong Kong Government has the authority to negotiate and conclude on its own final proposals on the following reform issues:

a. the rules and procedures for determining when a qualified person can have standing to be nominated;

\footnotetext{
${ }^{34}$ The Chairman of the NPCSC, Mr. Zhang Dejiang, was quoted as saying that the August decision "cannot be challenged or overturned" by the threat of protests, but it was not clear he meant that the conditions set in the decision could never change. See Julie Zhu, "Beijing's roadmap for HK 'cannot be challenged': Zhang Dejiang", ejinsight, 16 Sept 2014. But in the CE's Letter to Hong Kong (14 Sept 2014), he writes, "The NPCSC's Decision does not rule out the possibility of further changes to the method for selecting the Chief Executive after 2017. Indeed, the Basic Law does not say that the method for selecting the Chief Executive can only be amended once."
} 
b. the procedure for nominating two to three CE candidates in accordance with democratic procedures, whereby each candidate will have the endorsement of more than half of all the members of the nominating committee;

c. the design of the subsectors within each of the four sectors of the nominating committee, including the allocation of seats to each of the subsectors;

d. the rules for determining the electorate base of each of the subsectors of the nominating committee;

e. whether corporate voting will continue to be used in the election of nominating committee members;

f. the rules and procedures for eligible electors of the HKSAR to vote in an election of the CE;

g. the rules for determining the CE-elect by universal suffrage and the procedure for the appointment of the CE by the Central Peoples' Government;

h. whether the CE may continue to be affiliated with a political party.

Ultimately it will be for the NPCSC to approve the reform package, and in practice the Hong Kong government will consult the central government before putting a draft proposal before the legislature. Having taken such a strict position on the nomination process, to earn back public confidence, the central government should take a more relaxed view on these remaining reform issues and generally defer to the positions negotiated by the Hong Kong government.

\section{Hong Kong Government}

In trying to play a neutral role during the first round of consultation, the Hong Kong Government gave the impression that it did not stand up for the interest of Hong Kong people. ${ }^{35}$ In the next round of consultation, it needs to play a more

\footnotetext{
${ }^{35}$ The CE (C.Y. Leung)'s approval rating fell from 45 to 42 after the announcement of the NPCSC Decision. His lowest rating up to this time was 40 (survey from 14-21 Nov 2013). However, the Chief Secretary (Carrie Lam)'s rating increased from 54.9 to 55.2 over the same period. See Rating of Chief Executive Leung Chunying (per poll) (3/2012 - 9/2014) and Summary Table of Ratings of Principal Officials, charts available on the website of the Public Opinion Programme, The University of Hong Kong, accessible at http://hkupop.hku.hk/english/popexpress/ce2012/cy/poll/cy_poll_chart.html and http://hkupop.hku.hk/english/popexpress/poall/overall/datatables/datatables163.html.
} 
assertive role that strives to protect Hong Kong's interest. To help restore public confidence it should take charge of the remaining reform issues as outlined above and formulate positions that are more closely aligned to the people's aspirations for democratic rule. It should acknowledge the public's concern with central government control over the nomination process and come up with safeguards to allow the Hong Kong electorate a greater say in the final outcome of elections. Thus, it should embrace ideas such as having a low threshold for entering the nomination race, having a more expansive electorate base for each of the four sectors, requiring the CE-elect to have the support of $50 \%$ of all votes cast including blank votes, and allowing the $\mathrm{CE}$ to be a member of a political party. If on some reform issues opinions are sharply divided and reconciliation becomes difficult, an independent expert committee should be used to try to identify acceptable reform recommendations. Of all these reform ideas, the ability to cast blank votes is probably the most significant counterbalance. If the public does not have the power to reject all two or three candidates and none are desirable, because Beijing in influencing their nomination failed to take into account public opinion, then the likely consequence is that there will be significantly low voter turnout, thereby undermining the legitimacy of the winning candidate. ${ }^{36}$ In this regard, another counterbalance is to have a minimum voter turnout threshold, e.g. 75 percent, to confer greater legitimacy upon the final election result.

The Hong Kong government also has a role to play in helping to obtain the statements of reassurance from the central government. It needs to make its discussions with the central government on political reform more transparent. This will help to manage public expectations. We should not have to suffer another 'surprise' from the central government.

Ultimately the Hong Kong government must engage in meaningful negotiations with legislators. Significant efforts will be needed to get those who have already said they will not participate to the bargaining table. In addition to the reform concessions and the statements of reassurance, it may also be necessary to go further to show sincerity in achieving reform. With the current CE's low popularity ratings, ${ }^{37}$ the public may think that he does not personally wish to have universal suffrage in order to be re-elected under the existing system. The CE needs to find ways to dispel these beliefs. If statements cannot be given that the $\mathrm{CE}$ will not seek a second term of office then the next best thing is to engage in a process of power sharing. Pro-establishment legislators already occupy privileged positions in the executive arm; legislators at the other end need to be brought in. ${ }^{38}$ This will demonstrate that moderate legislators can

\footnotetext{
${ }^{36}$ The existing CE election system is also discredited by the low voter turnout rates for Election Committee elections. See Young \& Cullen, Electing Hong Kong's Chief Executive, pp. 73-74.

${ }^{37}$ See above $\mathrm{n} 35$.

${ }^{38}$ The three legislators who are also members of the Executive Council are regarded as pro-establishment figures, e.g. Regina Ip, Starry Lee and Jeffrey Lam. None of the current Principal Officials are legislators.
} 
be trusted by both the central and regional governments to take part in executive affairs. The current cabinet is due for a shuffle given the exceptionally low popularity ratings of a few ministers. If cabinet positions cannot be offered then membership in the Executive Council would seem to be a natural place to begin. Also power sharing by appointments to key government committees is another way to show sincerity.

\section{Legislators}

At a minimum, legislators must be prepared to engage in meaningful negotiations with the central and regional governments. As this paper has highlighted, there remains a wide range of matters to negotiate and upon which agreement might be secured. Legislators will also need to pay attention to public opinion. To ignore public opinion runs the risk of losing votes in the next election.

With the political environment so polarized, the conditions are fertile for a new moderate political force to take root, one that would threaten the extinction of the pan-democratic camp, as we know it now. This new political force would share the same core values as the pan-democrats, be critical of the pro-establishment camp, but willing to engage in dialogue with central and regional governments. Some members to be will already have the trust of the central government. The real question will be whether pan-democratic legislators will join this new political force by relinquishing opposition tactics and, as a first step, working towards an agreement on reform.

But having already made strong statements against reform, the dilemma for pan-democratic legislators is how to engage with government without appearing to backtrack. Hopefully there will be strong public opinion in favour of legislators engaging in a process of negotiation. Acting on public opinion and in the public interest are legitimate and respectable grounds for softening what was a strong and necessary position for the pan-democrats to take after the August decision. Vetoing any and all reform proposals runs the real risk of reinstating the incumbent $\mathrm{CE}$ and without any worthy plan of achieving better political reform the voting public should forgive pan-democrats for being pragmatic in a principled way.

\section{Hong Kong electorate}

Even though the Hong Kong electorate does not have a direct say in the negotiation between government and legislators, their opinions can be very important to the process. The public should make known to legislators whether they think the legislators should at least sit down to negotiate with the central and regional governments. The public should take part in the next round of consultation to make known what safeguards and other democratic features should be adopted on the remaining reform issues. It should continue to express 
its opposition to the restrictive nomination conditions set down in the August decision. This will serve to remind government that further and better reform to the nomination process is desired for future CE elections.

\section{Conclusion}

After the NPCSC's August decision, realising universal suffrage in Hong Kong now begins with good faith negotiations informed by public opinion. On one side of the table should be the Hong Kong government, because the central government will have already delegated authority to the local administration to handle this part of the process. On the other side are Hong Kong legislators, most likely pan-democratic legislators. A wide range of issues, beyond that of the 2017 CE election, should be up for negotiation. This is because mistrust will be the elephant in the room that must be addressed and overcome. Legislators will want reassurances from the same institution that caused the mistrust. They will want concessions on the remaining reform issues to counterbalance central government bias in nominations. Finally, power sharing may well be the incentive that secures the deal. What is at stake is not only CE universal suffrage it is the future of the Hong Kong political system and its potential transformation. 